\title{
P04.61. Do infectious disease (ID) physicians use cranberry for prevention of urinary tract infections (UTI)?
}

\author{
K Shere-Wolfe ${ }^{1 *}$, J Tilburt' ${ }^{2}$, C D'Adamo ${ }^{1}$, B Berman ${ }^{1}$, M Chesney ${ }^{3}$ \\ From International Research Congress on Integrative Medicine and Health 2012 \\ Portland, Oregon, USA. 15-18 May 2012
}

\section{Purpose}

The purpose of this study was to survey how ID physicians view cranberry for UTI prevention.

\section{Methods}

In a 2010 survey of 1000 ID physicians, we presented a case vignette about prevention of uncomplicated UTIs. "Ms. Smith is a 23 y.o. female who presents with a history of recurrent bacterial UTIs. In the past, she has self-treated with antibiotics at the first sign of infection; however she is now interested in preventing future occurrences. Previous work up has revealed no predisposing factors." We also presented a research summary of an article demonstrating evidence of efficacy of cranberry extract for UTI prevention.

\section{Results}

The overall response rate for the survey was $31 \%$. There were 292 responses for the question "Which ONE option best reflects your usual choice of initial management of UTIs in Ms Smith?". Fifty-four percent of respondents chose antimicrobial prophylaxis, $29 \%$ chose cranberry, and $17 \%$ chose "other". There were 298 responses for the question "Based on the research summary, how would you rate the comparative effectiveness of cranberry product versus trimethoprim for Ms Smith?". The majority of respondents found cranberry equally $(82 \%)$ or more $(4 \%)$ beneficial. Five percent felt that cranberry was less beneficial and 9\% felt that it was not at all beneficial. Finally, 301 participants responded to the question "Based on the information given, which ONE statement best characterizes your impressions about integrating cranberry products into the treatment plan for Ms. Smith?". Almost half (49\%) of

${ }^{1}$ University of Maryland, Baltimore, USA

Full list of author information is available at the end of the article respondents would consider using cranberry if the patient expressed an interest but only $22 \%$ would prescribe cranberry routinely. Twenty-five percent were not sure if they would use cranberry and $4 \%$ would not use cranberry.

\section{Conclusion}

Despite acknowledgement of the comparative efficacy of cranberry versus antimicrobial prophylaxis, the majority of ID physicians are not willing to prescribe cranberry routinely.

\section{Author details}

${ }^{1}$ University of Maryland, Baltimore, USA. ${ }^{2}$ Mayo Clinic, Rochester, USA.

${ }^{3}$ University of California, San Franscisco, San Francisco, USA.

Published: 12 June 2012

doi:10.1186/1472-6882-12-S1-P331

Cite this article as: Shere-Wolfe et al:: P04.61. Do infectious disease (ID) physicians use cranberry for prevention of urinary tract infections (UTI)? BMC Complementary and Alternative Medicine 2012 12(Suppl 1):P331.

Submit your next manuscript to BioMed Central and take full advantage of:

- Convenient online submission

- Thorough peer review

- No space constraints or color figure charges

- Immediate publication on acceptance

- Inclusion in PubMed, CAS, Scopus and Google Scholar

- Research which is freely available for redistribution 